\title{
Deliberative Inquiry: Integrated Ways of Working in Children Services
}

\section{Nada K. Kakabadse}

Professor in Management and Business Research

Northampton Business School

The University of Northampton Park Campus,

Boughton Green Road

Northampton, NN2 7AL, United Kingdom

International Tel: (0044) (0)1604 892197

E-mail: Nada.Kakabadse@,Northampton.ac.uk

\section{Andrew Kakabadse}

Professor of International Management Development

Cranfield School of Management

Cranfield, Beds, MK43 OAL, United Kingdom

International Tel: (0044) (0)1234 754400

International Fax: (0044) (0)1234 752382

E-mail: a.p.kakabadse@cranfield.ac.uk

\section{Linda Lee-Davies}

Senior Lecturer in Business and International Management

Northampton Business School

The University of Northampton Park Campus,

Boughton Green Road

Northampton, NN2 7AL, United Kingdom

International Tel: (0044) (0)1604 892148

E-mail: Linda.Lee-Davies@,Northampton.ac.uk

And

Nick Johnson OBE

Chief Executive, Hammersmith and Fulham Homes

Town Hall, Hammersmith, London W6 9JU

International Tel: (0044) (0) 2087534207

E-mail: nickjohnsonhome@,btinternet.com

Deliberative Inquiry: Integrated Ways of Working in Children Services 


\begin{abstract}
:
In striving for greater integration of children services across a number of government and non government agencies, this paper examines the effect of drawing on deliberative inquiry as the lever for realising greater alignment across agencies. The paper discusses the need for improvement in UK local government children's services and then offers a review of the dialogue based inquiry approaches. In so doing, the paper highlights the Socratic mode of inquiry, emphasising the dual strategies of penetrative questioning, elenchus, and the process of founding new knowledge through working through confusion, aporia. This paper then reports how a London borough realised sustained change through the adoption of deliberative inquiry. The study achieved successful integration through the penetrating and contextually sensitive dialogue the inquiry participants generated, allowing them to develop the capability for realising effective organisational change. The paper concludes that deliberative inquiry facilitates individuals to speak their concerns in a manner that prompts 'consensually accepted beliefs' to emerge through paying equal attention to the motivation of the inquiry participants, as well as to the reality of the contextual demands they need to confront.
\end{abstract}

Key Words: Deliberative inquiry, Children's services, Socratic deliberation, Integrated ways of working

\title{
Introduction
}


Local government within the UK has experienced considerable fluctuation concerning its role, mission structure and organisation (McEldowney, 2003). Yet, in embracing the challenge of change, public service strategies have been predominately evolutionary rather than revolutionary, as their focus has been on improving the quality of existing services rather than expanding the service and channel to market/citizen offering (Ajay, 2010). Despite its evolutionary nature, the need for flexibility within the public services is as strong as ever. From the expansion of service delivery channels, to changes in internal working practices, to integrated ways of working across the agencies, to partnerships with private-sector organisations, the focus has shifted from what public sector agencies do to how the organisation should run for the benefit of multiple stakeholders. Further, bottom-line objectives increasingly drive decisions that departments and agencies and their administration make, with problem-solving officials increasingly replacing the public servant bureaucrat (Kakabadse and Kakabadse, 2007). Research shows that numerous change initiatives such as privatisation, downsizing and fundamental reorganisation, spawning a 'more for less' culture, have also seriously damaged the employment relationship between public sector employees and their employers, resulting in a loss of trust between managers and staff and low levels of motivation, job satisfaction and morale (van Ruitenbeck and Makin, 1999; KPMG, 2010). Hence, finding new and more effective ways of managing change are mandatory if organisations are to avoid further damage to public sector employees' morale and ultimately, to the services that they deliver (van Ruitenbeck and Makin, 1999). 'Against a backdrop of low morale, reduced budgets, growing complexity and underlying change' (KPMG, 2010: 8), public services are now facing new challenges such as short-term cost reduction and efficiency improvement and in the long-term, redefining the role of the public sector. 'What it (public service agencies) should be doing and what it should stop doing because it is no longer 
affordable' (KPMG, 2010: 8) is the mantra of today, implying not only the cutting of expenses, improving efficiency, but also initiating strategic or radical transformation that includes identifying new funding sources (an initiative agencies have not yet realised).

Change has been a perennial organisational theme dating back to the ancient Greeks, and perhaps earlier. Some 2500 years ago, Heraclitus (1991) coined the maxim that "there is nothing permanent except change", holding that there is no permanent reality beyond that of change. The Chinese reflect their understanding of change in the term for "crisis", in Mandarin, "wei-ji ", which comprises the characters for "danger" ("wei”) and "opportunity" (“ji”), (Ming-Jer Chen, 2002). In more modern times, change has become the management mantra, and since the mid1980s a myriad of books and bourgeoning academic and popular literature (Kakabadse et al, 2007) reflect this. Public service has adopted numerous theories of organisational change for the public sector under the umbrella of new public management (NPM), (CAPAM, 2005; Bertucci, 2006; Siegel and Rasmussen, 2008).

Effective communication (Kakabadse et al 2009) is critical to the effective adoption of change methodologies. Organisational leaders are in constant search mode for the best communication practices within and across shifting organizational boundaries. Collaboration and integrated ways of service delivery, now more than ever, require that we collect and seek information and opinion in order to ensure that we make the most appropriate decisions that are aligned with the vision and direction that we are already pursuing. In support, Gergen, (1994: 264) for example argues that 'it is human interchange that gives language its capacity to mean, and it must stand as the critical locus of concern'. It is through human utterances that issues, biases and sentiments 
are surfaced, examined, confronted and dissolved which in so doing surface new issues. Kakabadse at al. (2007) posited that within collaborative inquiring groups, personal (concrete) levels of experience are lived and continuously re-negotiated (Kakabadse at al., 2007). Thus communication that engages is particularly relevant in sensitive public service sectors, such as children's services, where the free flow of information is crucial to ensure that agencies take correct actions.

In fact, the urgency for change and improved communication practice across organisational boundaries is a particular concern for children's services in the UK. Over the last two decades, the government has intensely scrutinised the protection of vulnerable children within the UK due to the number of child abuse cases and loss of child life which have been documented in a number of public inquiries into the perceived failure of public organisations (SSSS, 1974; DHSS, 1982; DH, 2002; DfES, 2003; Laming, 2003). Such scrutiny has also highlighted a particular concern over the increasingly prescriptive managerial approaches and the increasing incidence of apparent child care failures (Buttrick, 2000). With the publication of the green paper, Every Child Matters (DfES, 2003; HMSO, 2004), the government countered prescriptive managerialism with a requirement for the more flexible multi-agency cooperation. The green paper stated that each local authority should appoint a children's service director to lead the integration of multi agency children's services, as well as the development of the new trust organisation which will take over the chief education officers' and the social services directors' statutory responsibilities. It also required that a local authority must also appoint a lead councillor to take political responsibility for children's services. 
Although since the 1980s the government has encouraged professionals in local authorities, such as schools and health services, to collaborate (Davies, 1999), it has recognised the failure of formal collaboration across local authority institutions charged with the protection of children. The failure between agencies and professionals to build crucial links concerning information flows and complimentary actions is unsatisfactory, and leads to notably high profile cases of child abuse (Laming, 2003; Milburn, 2002; Clode, 2004). In response to the public outcry, government introduced an initiative, The Children's Trust, with the mandate to enforce the integration of professions into a single accountable organisation (HMSO, 2004).

Against this backdrop, this paper presents the case of how one London borough embraced the challenge of integration and change through a multi-agency deliberative inquiry process. Reflecting back, an assumption was made, namely that "professionals" in local authorities, such as local councils, schools and health services, hold the potential to drive through meaningful change in children-services practice, because of their capacity to both act upon their professional judgement, as well as their self-discipline and courage. However, other stakeholders such as children, parents or taxpayers in general,, were not called upon to participate in this inquiry. As this was an internally determined inquiry, driven by the objective of realising organisational integration, it was recognised that instrumental reasoning (or the applying of general principles) had to be subsumed by practical reasoning (phronesis), or common sense/prudence in order to provide for a service of high intrinsic value. Hence, the concern was to go beyond epistemic or "scientific" (Aristotle's episteme) inquiry with its focus on knowledge, belief, acceptance, verification, justification, and perspective, to "phronetic" (Aristotle's phronesis or practical 
wisdom) inquiry with a focus on deliberation particulalryparticularly concerning which social actions can be judged good or bad (Flyvbjerg, 2001), which in this case was the actions to be taken by the professionals in the provisions of children services. Thus, the borough in question adopted the Socratic approach to change as the most appropriate mode of action-based inquiry method. The reason for this is that the Socratic notion of deliberative dialogue serves as a sound framework for in vivo enhancement of learning, thus nurturing meaningful change. With such in mind tThis paper provides the background to the notion of integrated ways of working within UK children's services. The paper next presents a detailed account of the Socratic, deliberative dialogue mode of action inquiry. Highlighting the suitability of adopting Socratic philosophy to examine the organisational integration requirements within children's services, the paper offers comparative scrutiny of dialogue based inquiry approaches. It next presents a case study inquiry into a London borough children's services department. The paper concludes with the authors' findings that the Socratic interpretation of deliberative inquiry assisted the inquiry participants to embrace consensually accepted beliefs concerning professional practice, as the inquiry participants found the confidence and skill to speak as individuals, and as a result, clarified pathways through dialectical contrast.

\section{The Socratic Method of Inquiry}

Socratic dialogue has invoked inspiration and guidance for many contemporary scholars, not only those in philosophy and politics, but also from other disciplines such as education and psychology, irrespective of whether their aim has been to find the truth (i.e. truth seekers) or pursue open inquiry about their world (Table 1). Socrates drew on deliberative dialogue as the method of inquiry, positing that the inquirer was enabled to seek truth above all things. The 
essence of the Socratic argument is that deliberative dialogue deploys a consistent pedagogical approach by means of two particular strategies - the elenchus, or questioning method, and inspiring aporia, or confusion (Seeskin, 1986; Vlastos, 1991; 1993). His questioning technique, or the elenchus (i.e. refute or cross-examine), drew Socrates' interlocutors into common inquiry the process that led to the recognition that the interlocutors' beliefs required revision. Socrates alleged that knowing oneself to be uninformed is a far better state of affairs than possessing untrue beliefs. Recognition of being uniformed allows the person to release oneself of false beliefs that constrain reason and prevent learning. By probing each response of an interlocutor, examining whether one's entire set of beliefs are mutually consistent, the elenchus questioning breaks down old assumptions in order to build up new insights (Robinson, 1971; Vlastos, 1993). Thus, although the natural outcome of the elenchus is aporia, or confusion, more importantly, aporia arouses curiosity in the Socratic interlocutor who, being robbed of the certainty of his/her previous beliefs, recognises that he/she must begin searching anew. New learning can then take place as once one reaches a state of aporia, Socrates and his fellow inquirers stood on common ground, not pretending to possess ultimate knowledge or truth, but ready to engage in a collective search through further dialogue. In a similar vein, Schleiermacher (1998) argued that methods of natural science cannot accomplish the interpretation of human action as we must understand the human act as the act of a free subject, motivated by reason, and understood through dialogue.

Many scholars have valued dialogue that invokes both high energy and levels of learning (Habermas, 1979; Forester, 1983; Jaworski, 1996). However, dialogue and discussion crucially differ. Within discussion participants hold relatively fixed positions and argue in favour of their 
view, trying to convince others to change. In contrast, dialogue primarily requires the suspension of thought, impulse and judgment until a meaningful shared set of assumptions and insights emerge (Bohem, 1996).

However, deliberative inquiry is only one mode of learning through deliberation. Many approaches within the action learning umbrella exist (Reason and Bradbury, 2006; Kakabadse et al, 2007), such as action learning (Revans, 1997), action research (Toulmin and Gustavsen, 1996; Gustavsen, 2003; Flyvbjerg, 2001), action inquiry (Torbert, 2001), appreciative inquiry (Cooperrider and Whitney, 2005), and deliberative dialogue (Forester, 1999; Yankelovich, 2001; London, 2005), amongst other possibilities. The UK Civil Service, for example, has effectively used collaborative inquiry (CI) (Bray et al, 2000), (Kakabadse and Kakabadse, 2002) and the British National Health Service (NHS; Childerstone et al, 2004) has tried 'reflection in action' (Reynolds, 1999; Raelin, 2001; 2002) with success.

On the basis that not knowing what one does not know limits understanding and increases error, by entering into an exercise where one tries to find out what one doesn't know, one builds foundations for a better informed understanding and by implication, allows one to make more 'effective' decisions. Towards this end, Yankelovich (2001:41) championed Socratic dialogue as the way to migrate from discussion to dialogue, as in discussion, participants usually shy away from other participants' innermost assumptions in order not to violate unwritten rules of civility. However, in dialogue, participants uninhibitedly bring their own and other participants' assumptions into the open, 'as in the safe confines of dialogue others can respond without reacting judgmentally'. Although deliberative dialogue is a form of discourse aimed at finding 
the best course of action (Yankelovich, 2001; London, 2005), Yankelovich recognised that individuals and groups need to develop the capability for dialogue. In Ancient Greece, although society viewed deliberation as the process of establishing intent and resolve before settling on a specific course of action, they also recognised that interlocutions needed to mature into more sophisticated forms of conversation (Yankelovich, 2001). Since then, generations of scholars have affirmed the gain that can be realised through adopting Socratic dialogue as long as participants are allowed to actively develop. (Table 1).

Table 1: Acknowledgment of Socratic method by contemporary scholars

\begin{tabular}{|c|c|c|}
\hline Author & Discipline & Socratic Dialogue \\
\hline Nelson (1949) & $\begin{array}{l}\text { Philosophy } \\
\text { (neo-Kantian) }\end{array}$ & $\begin{array}{l}\text { Lamented the loss of Socratic method in philosophy and turned to } \\
\text { mathematicians and scientists to rejuvenate the Socratic search for truth. }\end{array}$ \\
\hline $\begin{array}{l}\text { Gadamer } \\
(1960 / 1989)\end{array}$ & Philosophy & $\begin{array}{l}\text { Socratic's inquiry at the heart of hermeneutical encounters (i.e. Socrates } \\
\text { understood he could not attain truth and instead led a life of perpetual } \\
\text { openness to dialogue and questioning). }\end{array}$ \\
\hline Rorty (1988) & Philosophy & $\begin{array}{l}\text { Admired Socrates' epistemological humility and his value as symbol of } \\
\text { continual curiosity and openness, referring to his work as "Platonic Socrates" } \\
\text { and a "Deweyan Socrates". }\end{array}$ \\
\hline Dewey (1935) & Philosophy & $\begin{array}{l}\text { Provided foundation for democratic ideas and importance of an emerging } \\
\text { public as an agent of change - means for creating "socialised intelligence". }\end{array}$ \\
\hline Mill (1863/2002) & Politics & $\begin{array}{l}\text { Adopted doctrine based on Socrates that we assess happiness not merely by } \\
\text { quantity, but by quality. }\end{array}$ \\
\hline Bloom (1987) & Politics & Socrates' unassailable quest for truth. \\
\hline Reich (1998) & Politics & $\begin{array}{l}\text { Socratic paradigm of open inquiry or "moral Socrates"; referred to Socrates' } \\
\text { earlier dialogues, whilst Socratic paradigm of truth-seeking and knowledge or } \\
\text { the "metaphysical Socrates" referred to middle and later dialogues that, } \\
\text { perhaps due to Plato's influence, appeared more concerned with matters of } \\
\text { truth. }\end{array}$ \\
\hline Adler (1982: 29) & Education & $\begin{array}{l}\text { Paideia proposal "must be the Socratic mode of teaching, a mode of teaching } \\
\text { called maieutic because it helps the student bring ideas to birth". }\end{array}$ \\
\hline Matthews (1981) & Education & $\begin{array}{l}\text { Socratic dialogue engages young children, teaching them in the process the } \\
\text { activity of philosophising. }\end{array}$ \\
\hline Maranhao (1986) & Psychology & $\begin{array}{l}\text { Sigmund Freud adopted much from the Socratic method in constructing a } \\
\text { theory of psychoanalysis around dialogue. }\end{array}$ \\
\hline $\begin{array}{l}\text { Kohlberg (1981: } \\
\text { 3) }\end{array}$ & Psychology & $\begin{array}{l}\text { The "way out from the Scylla of indoctrination and the Charybdis of 'laid- } \\
\text { back' relativism or values clarification - Socratic dialogue to stimulate stage } \\
\text { development". }\end{array}$ \\
\hline Bohem (1996) & Quantum Physicist & $\begin{array}{l}\text { Deliberative dialogue as a form of discussion aimed at finding the best course } \\
\text { of action. Practice focused on learning, unpacking assumptions and facilitating } \\
\text { communication that transcends ritualised confrontation, fostering deep }\end{array}$ \\
\hline
\end{tabular}




\begin{tabular}{|l|l|l|}
\hline & & inquiry. \\
\hline $\begin{array}{l}\text { Yankelovich } \\
(2001)\end{array}$ & Social Science & Deliberative dialogue as a process of revealing hidden assumptions. \\
\hline $\begin{array}{l}\text { Kakabadse and } \\
\text { Kakabadse (2003) }\end{array}$ & $\begin{array}{l}\text { Management } \\
\text { Research }\end{array}$ & Socratic dialogue underpins various forms of action-based inquiry. \\
\hline
\end{tabular}

Socrates emphasised that through dialogue, the actor does not speak with any pretence to knowledge. Rather, he searches for it through inquiry along with his interlocutors (Socrates, 1961: Apology, 21b; Euthyphro, 5a-c; Gorgias, 506a; 508e; Republic I, 337e). For example, in Charmides, Socrates (1961: 165b) replies to the astonished Critias, "You come to me as though I professed to know about the questions which I ask, as though I could, if I only would, agree with you. Whereas the fact is that I am inquiring with you into the truth of that which is advanced from time to time, just because I do not know".

Socratic inquiry powerfully illustrates the ideal of constant openness and eagerness to enter into deliberation with others, whilst simultaneously holding expectations that from such dialogue, participants will not establish the final truth. Rather, emergent learning will provide the opportunity for a common consensus amongst the inquiring participants (Seeskin, 1986). In effect, Socratic reflexive praxis provides a meaningful way for participants to gain genuine understanding through processes that "involves first, a state of doubt, hesitation, perplexity and mental difficulty from which thinking originates, and second, an act of searching, hunting, and inquiring to find material that will resolve the doubt and settle and dispose perplexity" (Dewey, 1933: 12), whilst still allowing participants to evaluate the significance of their experiences within their context (Gustavsen, 1992). That is, "only when people can communicate on free and 
equal terms can they achieve the deep self-understanding that we have hankered after since the enlightenment" (Dewey, 1933: 12).

Thus, Socratic dialogue is attractive for the purposes of modelling common inquiry and for aligning group and civic participation. The Socratic method offers both the pedagogical potency to develop analytical skills and the inquiring habit that is invaluable for engagement to achieve meaningful change (Seeskin, 1986). Reich (1998: 222) argues that the "Socratic method is important less for its drive at 'moral education' than for its capacity to further 'civic education'”, Although, the Socratic dialogue ideal is not always achievable, the Socratic, Maieutics principle., (definition and induction) of penetrating interchange between individuals with opposing viewpoints through the asking and answering of questions to stimulate critical thinking in order to search fortease out commonly held truths that shape opinion, encourages an enduring scrutiny. Through engaging in Socratic discussions, the individual can become more adept at critical thinking, improve their listening skills, learn to better articulate thoughts and ideas, and, as a result become more tolerant of diverse opinions (Ronald, 1992).

Overall, one can argue that all epistemologies fall in one of the two basic categories, namely Socratic or Aristotelian. One can interpret the Aristotelian approach towards deliberative dialogue as too theoretical in an effort to try to neutralise emotions, passions and identities in the name of rational reasoning and the enabling of logic for better argument (Fischer, 2009:82:27294). Aristotelian epistemology takes a teleological position, emphasising cause and end or goals, and as such, is motivated towards the discovery of truth and knowledge, through the search for 
underlying principles. In this sense, Aristotelian epistemology relies on a shared rationality and objectivity, leading to "scientific" knowledge rather than "practical" knowledge.

\section{Deliberative Inquiry}

By embracing the Socratic principles of facilitating self audit and self development, deliberative inquiry is a dynamic process which sets out to accommodate participants holding different perspectives. Deliberation played an important role in ancient Athens because it was instrumental to the exercise of democracy. Some 2400 years ago, Socrates used deliberation as a method for seeking deeper understanding - a way of seeking the truth through inquiry. Even at his trial in 399 B.C., Socrates (Plato, 1997: 38a) urged his fellow citizens to examine their lives in elenchic conversations (elenchos-from the Greek term for refutation), maintaining that, "the unexamined life was not worth living”. Such enthusiastic and vigorous debating became diluted over time and led to the rise of modern 'empiricism', championed by Francis Bacon. Philosphers favoured rational empiricism and experimentation over deliberation, which currently dominate in our search for knowledge in world science. Francis Bacon expounded scientific experimentalism, believing that we must force Nature to answer the questions put to her as "Nature exposes herself more rapidly when she is tortured than when she is free ... Nature needs to be constrained, tortured, forced out of her natural state by the hand of man, squeezed and moulded" (Sir Francis Bacon quoted in Merchant, 1982: 169). Seventeenth century Baconian methods still dominate much of modern scientific research. Bacon's ideas set in the Advancement of Learning in 1605, propagated his description of science as a four-stage process of observation, induction, deduction and experimentation, a platform that has dominated science for the last 400 years. 
Under such onslaught, deliberative inquiry faded. However, the Socratic art of dialogue and Plato's dialectical logic (Cooper and Hutchinson, 1997) resurfaced in the $18^{\text {th }}$ century, first resuscitated by Kant (1929), then expanded on by Hegel (1806/1975) and ultimately, the German scientists Von Goethe and Naydler (1996) revived the Socratic method of inquiry. Better known as a poet (author of Faust), Goethe (1987) was also a scientist who practiced a method he named 'zarte empirie' (delicate empiricism). More than a century later it reemerged as existential phenomenology (Van Manen, 1990). Existential phenomenology holds that the individual needs to 'stay with' the experience, which acts as the basis for generalisation and interpretation. Goethe's interpretation of science moved away from quantitative, materialist approaches to life as nature and emphasised intimate firsthand encounters between the inquirer and the subject.

Goethe's (1987) contribution was a significant step in the reawakening of deliberative inquiry. With the increased pace of automatisation, measurement and the further disintegration of the workplace (Karoly and Panis, 2004), scholars once again recognised the value of Socratic deliberation's deep discussion, particularly between the mid-1960s and mid-1970s, under the umbrella of action-based research. Sometimes explicitly acknowledged and sometimes just implicitly inferred, Socratic dialogue acted as the basis of "communicative action" (Habermas, 1985 ) and the myriad of action based inquiries, such as "participative action research (PAR)", "co-operative inquiry (CoI)", "collaborative inquiry (CI)", "appreciative inquiry (AI)", clinical inquiry, community-based research, diagnostic practice, and reflective practice (Table 2). As such, scholars position deliberative dialogue as a "practical discipline" rather than a homogeneous theory (Craig, 1989) Its multidisciplinary nature transcends many fields of 
specialisation: philosophy, linguistics, political science, organizational development, psychology, sociology, education, social work, public relations, conflict resolution, communication theory, and with its practical orientation, provides a continuous bridge between theory and praxis, thus forming "conversational hybrids" (Barge and Little, 2002: 379; Stewart and Zediker, 2000; Stewart et al, 2004). Creating space for deliberative dialogue and in turn, dialogic communication, is an evolving craft rather than a fixed technique. Deliberative dialogue requires discipline, time, and a willingness to reflect on communication habits and patterns of power relationships, and simultaneously enables participant inquirers to experience different ways of relating to others (Craig, 1989; Ryfe, 2002; 2005). Within deliberative practice, we understand truth and knowledge as "consensually accepted beliefs" within evolving conversations (Fischer, 2003:131) which are grounded within a normative validity (Linder, 2001). Despite its emphasis on the participant inquirer, there remains a need for skilful facilitators who must invest considerable time and energy in enthusing participants to discover common ground and overcome language barriers which are often steeped in the legacy style and specialised jargon of the "shared vocabularies" of their networks (Miller and Rose, 2008:34-5). Facilitators assist the inquiring group in the "problematisation and exploration of their own concerns and interests" (Fischer, 2003:216).

Table 2: Dialogue based inquiry approaches

\begin{tabular}{|l|l|l|l|}
\hline \multicolumn{1}{|c|}{ Characteristics } & \multicolumn{1}{|c|}{$\begin{array}{c}\text { Deliberative } \\
\text { Inquiry }\end{array}$} & $\begin{array}{l}\text { Collaborative (and/or } \\
\text { Cooperative) Inquiry }\end{array}$ & \multicolumn{1}{c|}{$\begin{array}{c}\text { Participatory Action } \\
\text { Research }\end{array}$} \\
\hline Purpose & $\begin{array}{l}\text { To expand the understanding of } \\
\text { each inquirer's own experience } \\
\text { by understanding of self and other } \\
\text { inquirers, and together to develop } \\
\text { new understanding of shared } \\
\text { phenomena under inquiry. }\end{array}$ & $\begin{array}{l}\text { Creating shared meaning } \\
\text { (co-creation of group } \\
\text { knowledge) and change } \\
\text { through learning. }\end{array}$ & $\begin{array}{l}\text { Social transformation (re- } \\
\text { addressing power } \\
\text { imbalances). }\end{array}$ \\
& $\begin{array}{l}\text { Awaking from dogmatic slumbers } \\
\text { into genuine curiosity and creation }\end{array}$ & Knowledge co-creation for change within context. \\
\hline Aim & \multicolumn{2}{|l}{} \\
\hline
\end{tabular}




\begin{tabular}{|c|c|c|c|}
\hline & $\begin{array}{l}\text { of shared meaning (or consensus) } \\
\text { amongst all participants. }\end{array}$ & & \\
\hline $\begin{array}{l}\text { Ontological } \\
\text { assumptions }\end{array}$ & $\begin{array}{l}\text { Reality of the world of external } \\
\text { nature and internally and socially } \\
\text { constructed interactions. }\end{array}$ & \multicolumn{2}{|c|}{$\begin{array}{l}\text { Reality is a unity of the natural and social world } \\
\text { (objectively given), in which humans are participatory and } \\
\text { self-determining (inter-subjectively interpreted). }\end{array}$} \\
\hline $\begin{array}{l}\text { Epistemological } \\
\text { positioning }\end{array}$ & $\begin{array}{l}\text { Focus on attainment of } \\
\text { consistency rather than certainty } \\
\text { (i.e. epistemological humility). }\end{array}$ & \multicolumn{2}{|c|}{$\begin{array}{l}\text { Generative dance between four types of knowledge - } \\
\text { prepositional, practical, experimental and presentational. }\end{array}$} \\
\hline Paradigm & $\begin{array}{l}\text { Perpetual learning (i.e. deliberative } \\
\text { discovery). }\end{array}$ & \multicolumn{2}{|c|}{ Participatory (critical engagement). } \\
\hline Focus & Group of equal participants. & Group & Community \\
\hline Methodology & Democratic deliberation. & $\begin{array}{l}\text { Extended epistemology } \\
\text { (cycles of action and } \\
\text { reflection). }\end{array}$ & $\begin{array}{l}\text { Inquiry cycle -varies by } \\
\text { groups (of secondary } \\
\text { concern). }\end{array}$ \\
\hline $\begin{array}{l}\text { Methods for } \\
\text { collecting empirical } \\
\text { material }\end{array}$ & $\begin{array}{l}\text { Primarily Socratic dialogue (i.e. } \\
\text { elenchus and aporia). }\end{array}$ & \multicolumn{2}{|c|}{ Primarily polylogue/dialectic discourse. } \\
\hline $\begin{array}{l}\text { Methods for } \\
\text { empirical material } \\
\text { analysis }\end{array}$ & Reflective interaction. & Reflective dialogue. & Interaction. \\
\hline Logic & Deliberation. & Dialectics. & Polylogue. \\
\hline Role of inquirer & $\begin{array}{l}\text { Multi-faceted (e.g. inquirer, } \\
\text { creator, subject of inquiry, } \\
\text { purveyor of wisdom). }\end{array}$ & \multicolumn{2}{|c|}{ Dual: Co-researcher and co-subject. } \\
\hline Ideology & $\begin{array}{l}\text { An examined and contemplated } \\
\text { group/individual life. }\end{array}$ & \multicolumn{2}{|c|}{$\begin{array}{l}\text { Democratic research with people (participants are both } \\
\text { subject and co-inquirers). }\end{array}$} \\
\hline $\begin{array}{l}\text { Number of } \\
\text { participants }\end{array}$ & $\begin{array}{l}\text { Varies, ten federations of small } \\
\text { groups. }\end{array}$ & $\begin{array}{l}\text { Five to } 12 \text { people (may } \\
\text { cluster into a federation } \\
\text { of several CI groups). }\end{array}$ & $\begin{array}{l}\text { Varies from small to large } \\
\text { group interventions. }\end{array}$ \\
\hline Facilitator's role & $\begin{array}{l}\text { Socratic role - engage deliberation } \\
\text { within the group of inquirers. }\end{array}$ & $\begin{array}{l}\text { Role shifts into a co- } \\
\text { inquirer (may be an } \\
\text { initiator of the group or } \\
\text { external). }\end{array}$ & $\begin{array}{l}\text { Organiser/researcher } \\
\text { knowledgeable in range of } \\
\text { research methods and group } \\
\text { processes. }\end{array}$ \\
\hline Validation & $\begin{array}{l}\text { Normative-contextual and } \\
\text { ecological validity recognising } \\
\text { inquirers truthfulness, clarity, } \\
\text { sincerity and legitimacy of group's } \\
\text { mutual accountability for } \\
\text { differentiated validity claims. }\end{array}$ & \multicolumn{2}{|c|}{$\begin{array}{l}\text { Participants build, test and enact their theory through } \\
\text { democratic dialogue, dialectical debate and shared } \\
\text { meaning. }\end{array}$} \\
\hline Thoughtfulness & Civic participation and engagement. & \multicolumn{2}{|c|}{$\begin{array}{l}\text { Collaborative encounter with experience (critical } \\
\text { subjectivity). }\end{array}$} \\
\hline Outcomes & Meaningful qualitative change. & \multicolumn{2}{|c|}{ Transformational/qualitative change. } \\
\hline
\end{tabular}

Source: Adapted from Kakabadse et al (2007)

The goal of deliberative inquiry is to create a special environment in which a different kind of relationship amongst parties comes into play, and which has an underlying feature of high 
energy. In so doing, it creates opportunities for participants to constantly reflect on their experiences and learn. Whilst deliberative inquiry emphasises the process of deliberation itself, it is also concerned with examining and comparing different settings and procedures as well as the problems and constraints that one cannot always anticipate by conceptual argument alone. Fundamental to deliberative inquiry is democratic Socratic dialogue which, in addition to providing a forum to cast issues 'in the open' or 'out there' into a public space, provides a forum to further explore their relational nature within a 'relational landscape', or in a 'dialogical space of possibilities' (Shotter and Katz, 1996) that we evoke in order to examine existing assumptions and create new and shared meanings. It is an ongoing flow of activity constituting new inquiring cycles based on mutual involvement from which participants emerge with a new understanding of what Wittgenstein (1980: 26) terms a "proper synopsis".

\section{Deliberative Inquiry's Background to the Integrated Ways of Working in Children}

\section{Services}

Aware of the pitfalls of previous government initiatives concerning prescribed change and cognisant of the literature that suggests that defensiveness (Mazen, 2002) and mistrust (Jaques, 1976) prevail in inhibiting change, a London borough CEO embarked on a journey of change. Faced with task of establishing a children's trust (HMSO, 2004), and the responsibility to ensure that the local council fulfils it statutory obligations and delivers appropriate service, the CEO considered a route to change through participatory action-based inquiry into how professionals in the newly structured agency should work together. The CEO had long professional experience within the public sector and the informed assumption that ownership of change is essential for success (Bazerman, 1986). He also knew, from his painful experience, that prescribed change 
can have a negative impact on the professional actor (Hunter, 1992). This CEO knew that nobody could take for granted the success of a collaborative team implementing change and emerging from a legacy local situation (King et al, 1993: 445). To assist with the inquiry process, the CEO enlisted two academics in the role of inquiring advisors. At the first meeting with the advisors present, the inquiring CEO voiced his concern regarding the perceived challenges he faced:

"This is not a small change; it also implies a merger or a fusion of professional roles, responsibilities and goals. ... It also may imply removal, duplication or separate accountability, which may lead to some sort of re-codification of the way the job, is actually done. In addition, there is the issue of the skills and competencies needed to enable the new system to be put in place. My 30 years experience in the public sector has taught me that a managerialistc prescriptive formula of change will not work. It never has. I need to do something different, to engage people in a meaningful way, even if that is the last thing I do."

Socratic deliberative inquiry appeared as a fitting approach for this project, bearing in mind the various inquiry methods within the action inquiry paradigm (Table 2). The Socratic method appeared the most relevant to the inquiry participants because they considered it sufficiently flexible to accommodate the participant inquierers' variety of views and contrasting philosophies. Wilmot's (1995) study of clinical teams in hospitals revealed that 'dialogue' influences success at hand. He found that "dialogue facilitates discussion of team philosophy, values and shared approach to quality service provisions" (Wilmot, 1995: 157). Similarly, 
McCallin's (2001: 281) research emphasised that when team members do not "well establish dialogue, service provisions deteriorate because they are unwilling to discuss and work through their differences and put clients into the centre". The CEO purposely embraced the decision to adopt deliberative inquiry as the mode of engagement for the inquiry group on the basis that they 'needed to step back and go back to basics' (Participant, 2). As an organisation, the agency had experienced many upheavals, 'unsuccessfully' drawing on numerous methodologies and consultant models. This time they were determined to use something 'very basic that works', which they concluded to be Socratic "dialogue". A member's reading of Bohem (1996) further affirmed the group's decision, with the conclusion that dialogue is essentially a conversation between equals and that Socratic dialogue is an invitation for learning.

Once the group adopted deliberative inquiry, the CEO "blended" into the group's background and became one inquiring participant. This emerged as an important factor for the deliberative process and perhaps, a critical factor in the group's success. Experienced, charismatic, well known and politically astute, the CEO had the 'gravitas' to take the group in any direction. However, his natural curiosity and will for learning had him position himself as a co-inquirer.

\section{The Inquiry}

In order to gain the participation of the relevant agencies for the inquiry, the CEO sent a letter of invitation to a range of professionals involved in meeting children's needs in a particular geographic part of London. Entitled "New Children's Service: Help us get it right", the letter explained the inquiry's aim, namely, how to effectively integrate professional judgment and decisions on behalf of improving services for children. The host inquiring group sought to elicit 
participation across education, social care and health service, as well as the borough council concerned and approached a vertical cross-section of staff - from strategic management to senior operational officers. Some 29 professionals responded positively and the CEO invited 15 volunteers to form a steering team, with the intention that they would, overtime, involve other services, such as police, probation services and the voluntary sector in the project's second phase. The CEO initiated the inquiry in 2005, and it is still ongoing. In order to capture the experience and possible benefit of drawing on deliberative inquiry as a mode for facilitating change, this paper only touches upon issues which involve more complex ongoing changes in one local authority and its related agencies.

At the first meeting, and in the spirit of forming a platform from which evaluative opinion would emerge, discussion focused on whether inquiring participants clearly understood deliberative inquiry. This first gathering enabled participants to 'get to know each other' and to explore the meanings they attached to the current integrated ways of working.

Four key themes emerged as requiring greatest attention for deliberation, namely, the meaning of integration, recognition of the need for change, expectations from integrated ways of working and the 'real' issues.

\section{Meaning of Integration}

The inquiring participant across the participating agencies concerning integration held a 'means rather than ends' interpretation. 
"Integration is not the goal, but rather a means for achieving better services for children and their families."

Child Care Unit Practice Manager, Social Services

"There is a huge gap between the way in which we, as professionals, now work and collaborate and the stated government vision for integrated service - realistically integration means improving current ways of working."

Community Paediatrician, Health Services

"Integration means being able to help the child with the difficulties it faces when the time is right. It means a completely new way of working together and not focusing on meeting targets for the sake of it."

Education Welfare Officer, Primary School

"For me, integration means working as a real team."

Financial Manager, Borough Council

The inquiry participants expressed a shared vision of end user benefit from their greater pursuit of integration of effort and collaboration across the relevant agencies. Notably, the comment on targets reveals the nature of the underlying problems of how things were before and suggests that personal idiosyncrasies influencing performance may have, at one time, over taken real purpose. 
Also, each member held different views concerning the nature of integration but all agreed that the agencies needed improvement.

\section{Recognition of Need for Change}

Required to respond to an ever greater number of government initiatives for change, the inquiry participants expressed varying awareness levels to the unique nature of this particular programme of change, or the need for change in the first place. Only after some discussion, the participants started to verbalise their appreciation of the need for change to improve service delivery.

“Children's bill or not, sharing information amongst fellow professionals must happen, especially between health and social services colleagues if we are to achieve improvement on the current situation."

Senior Social Worker, Social Services

"We really need a much better way of working together, where we feel that we all have an equal say in the way decisions are taken."

Financial Manager, Borough Council 
"Improvements to the current service are necessary, but improvements through combined services will not happen overnight ... Changing people's ways of working, responding to continuous government initiatives and cutting costs are challenging tasks."

Head Teacher, Secondary School

Some two and a half months into the inquiry the collaborators were 'struck' by their increased awareness that their current practice required improvement and that their agency was considering new ways of integrated practice.

\section{Expectations from Integrated Ways of Working}

By reflecting on their existing practices and identifying areas of improvement, the inquiry participants shared their expectations for new ways of working, as well as their forming of healthy doubts of the value of the inquiry.

"I am hoping for better outcomes for children, improved care and teamwork but, based on my experience, I'm not holding my breath."

Child Care Unit Practice Manager, Social Services

"Integration must achieve maximising resources, sharing information, a more cohesive approach, challenging, less political and more services responding to the actual needs."

Community Paediatrician, Health Services 
"I hope that this process will reduce the number of complaints we receive, as well as help us quickly pinpoint problem areas."

Officer, Borough Council

The comments suggest that the inquiry participants were taking responsibility for service integration across the relevant agencies. Their desire for a successful collaboration was becoming embedded in the inquiry team's thinking.

One significant factor of deliberative inquiry is that once participants start sharing their thoughts and doubts, they become inquiry subjects themselves that others can examine. Once the issues are 'out there' in the common space between group members, these inquiry participants also function as a shared resource of already established topics, or shared common places that group members can draw upon and refer to in their deliberation. Thus, in addition to providing a forum to get issues 'in the open', dialogue also provides the space to further explore their relational nature within a 'relational landscape', in a "dialogical space of possibilities" (Shotter and Katz, 1996) of experiential events, that participants evoke in order to create a shared knowledge.

\section{The "Real" Issues}

By nature, deliberative inquiry is an iterative process and as such the 'real' issues merged as a topic of deliberation only during the $11^{\text {th }}$ cycle. All discussed issues were important to the participants, as they formed an elaborative common platform for sharing. Wittgenstein (1980: 26) terms this as "a synopsis of trivialities" that get enriched at each meeting, whereby the depth and openness of sharing became more evident cycle by cycle. The inquiry participants drew on a 
communal "space of resources", creating what Taylor (1985: 264) refers to as "entre nous", a space distinctive before them.

"In a way this is a humbling experience, learning how to seek support and advice from my peers. It both assures me, but at the same time it questions my professional confidence."

Teacher, Special Needs School

During deliberative inquiry, participants create a common ground in which they recognise, accept and value each contributions' uniqueness. The diversity in perspectives, identities and potential contribution ensures a broad problem definition, creativity and completeness in generating solution alternatives. This legitimises the chosen strategy, and creates the energy and commitment for implementation and finally, the governance of the deliberative system.

After the first year of the inquiry, the group not only formed a blueprint identifying how the professionals themselves saw the new interaction patterns within the Trust, but were also acting as an integrated team. In fact, the participating members of one of the 37 local authorities in the pilot wave assessing integrated ways of working, felt confident that government would positively assess their effort during spring 2006. Whilst one can fabricate target results that others set (Ball, 2003), the participants felt that they had achieved their aim by considerably reducing, if not eliminating, the defensiveness (Mazen, 2002) and mistrust (Jaques, 1976) that often prevails and 
inhibits change initiatives. Based on reasoned, open, reciprocal and deliberated communication, the inquiry participants reached an understanding on how to coordinate their future activities through normative commitments. Their normative agreement served as a social building block, based on deliberated communication rather than manipulation or coercion.

"Perhaps we are not the most innovative group of people, but our new way of working is grounded in the needs of the service users - children and their family. We now have created a model of information exchange that will enable us to make informed and timely decisions. Most importantly, we know how to work with each other."

Education Welfare Officer, Education

\section{Discussion}

Although deliberative inquiry cannot claim universal truth, deliberative inquiry results hold contextual and ecological validity because its strength of pluralism in a multi-cultural society, with widely varying accounts of work and life issues, enables individuals and groups to confront and act upon their reality. Considering that no one conclusively possesses the best ways of dealing with an issue, then only a systematic deliberation of all participants may lead the way in finding discovering the best and most beneficial way forward within each context. Thus, deliberative inquiry offers critical examination of beliefs and emotions so as to discover appropriate pathways through constant openness and eagerness to enter into dialogue with others (Reich, 1998). The Socratic method does not offer an inversely valid solution or generalisable 
results, but rather can powerfully help practitioners acquire the critical thinking skills and habits necessary for active involvement in a pluralist and multi-faceted work context.

The inquiry participants in the children services study evolved to discover the benefits of investing in this wider accommodation of views. It did not happen instantly, but developed over a number of cycles, as participants established trust and familiarity. Participants did not "battle out" different agendas and even different understandings of integration. Instead, they shared views and experiences and this resulted in reaching a collective direction to improve the service for the end user rather than abuse the arena to strengthen individual member cause. Through active involvement, collaborative interaction subsumed potential power relationships (Kakabadse and Parker, 1984). Further, the qualitative data the inquirers gathered fresh from the collective environment could not accurately represent any scientific gain in detail. Rather, it provided an indication of events and intentions on a cumulative basis and noted the pluralist evolution. Luke and White (1985: 25) suggest that "communicatively competent actors have the capacity not only to dispose reflectively ..... but also to raise the respective types of validity claims in their own speech acts as well as to evaluate critically the claims made in the speech acts of others", in relation to truth or success (i.e. assertions about a world of objects and states of affairs), legitimacy (i.e. a world of social norms) and truthfulness or authenticity (i.e. a world of subjectivity). Being accessible, easily grasped and linked to commonly understood truthful norms appeals to those who desire to improve practice (Sutton, 2001). This spirit was clearly present in the study where participants showed the benefits of pursuing this line of working together, both as a whole benefit and as an individual gain. 
The desire to improve practise has to be a key element in the portfolio of skills and attitudes of the modern leader. The chief executive of the local authority in question had that desire and was willing to risk putting the practise into place to improve matters in children services. In pursuit of the highest levels of effectiveness in order to furnish their overall strategic aims, leaders in the current competitive markets would benefit from ensuring that they are in a position to make the most appropriate decisions at ground level through designing their strategic aims to suit the current environment. The further the leader is from the front line of his/her service or business, the harder it is for them to make accurate decisions from the management information he/she receives. The free flow of current and actual experience is essential from those who are more front facing. They must merge the quality data with the strategic minds that decide the way forward, as well as the methods of arriving there.

In addition to making the organisation responsive to its end users, there are positive by-products of the process in human terms. If leaders are more willing to allow the time to design a forum for debate, they not only perpetually enlighten themselves, but also the participants, as this inquiry study reports. Further, the self continuity of the process accelerates in that once the culture accommodates this manner of cross organisational dialogue and importantly, the accompanying mutual respect for all inputs and the constant questioning and review of practise, the organisation is reinvigorated from its core. This gives the whole entity the proactive, perceptive power to succeed in the long term and reduces the need for the panic reactivity for short term survival, as well as the end user's risk of the agency short changing him/her of a vital service. 
Ryfe's (2002:369) analysis of sixteen cases of deliberative discourse illustrates that 'there is no such thing as one form or format of good discourse. Deliberation is inherently rooted in context, and different kinds of contexts demand different kinds of conversations'. Within the children services context, deliberative dialogue helped participants speak not only as individuals, but as members of their own organisations, not only as groups with competing interests, but also as a community with shared interests, shared concerns and shared goals for children within their responsibility. The "consensually accepted beliefs" that evolve through inquiry conversations are steeped in normative validity that allow us, for the time, to identify ways forward through increasingly developing commitment for a deliberately chosen course of action. In the children's service's case, deliberative dialogue redefined the role of technical expertise within each individual service provider organisation by counterbalancing it with a simultaneous reliance on the experience and the local knowledge of the individuals involved in service delivery. With the benefit of post hock reflection, the inquiry process could have taken any turn and could have derailed at any time, in particular, during the first few months of the inquiry. The inquiry participants' dedication and the CEO's maturity enabled the inquiry to take the direction that it did. Overall, the inquiry facilitators' input and contribution was not critical to the process. Even the most skilful facilitator can derail an inquiry if there is insufficient desire amongst the participants to see the process through. In effect, one needs to counterbalance the pursuit of deliberative theory with equal attention to the motivation of the inquiry participants engaged in the process (Chambers, 2003:307). 


\section{References}

Adler, M. (1982) The Paideia Proposal: An Educational Manifesto. Macmillan USA, USA.

Bacon, Francis, Verulam, Lord (1962) The works of Francis Bacon, Vols. I-XIV, Edited by J. Spedding, R. L. Ellis, and D. D. Heath, Longman, London.

Ball, S. (2003) 'The Teacher's Soul and the Terrors of Performativity', Journal of Education Policy, 18(2), 215-228.

Bazerman, M. (1986) Judgement in Managerial Decision Making. New York: John Wiley \& Sons, Inc.

Bertucci, G. (2006) 'Strengthening Public Sector Capacity for Achieving the Millennium Development Goals' in Rosenbaum, A. and Kauzya, J-M. (Eds. Excellence in Leadership in the Public Sector: The Role of Education and Training, United Nations, New York, pp. 195-201.

Bloom, A. (1987) The Closing of the American Mind/How Higher Education Has Failed Democracy and Impoverished the Souls of Today's Students. Simon \& Schuster, USA.

Bohem, D. (1996), On Dialogue, editor Lee Nichol, London: Routledge.

Boyd, E.M. and Fales, A.W. (1983) 'Reflective Learning: Key to Learning from Experience', Journal of Humanistic Psychology, 23(2), 99-117.

Bray, J., Lee, J, Smith, L.L. and Yorks, L. (2000), Collaborative Inquiry in Practice, Sage, London

Buttrick, R. (2000) Project Workout: A Toolkit for Reaping the Rewards from All Your Business Projects ( $2^{\text {nd }}$ Edition). Harlow: Financial Times Prentice Hall.

CAPAM (2005) In Pursuit of Excellence: Developing and Maintaining A High-Quality Public Service, A Report on a CAPAM High-Level Seminar on Commonwealth Training and Development Institutes, Ottawa, October.

Chambers, S. (2003), 'Deliberative Democratic Theory', Annual Review of Political Science 6; pp. 307-26.

Childerstone, S., Gorli, M. Nicolini, D., and Sher, M., (2004), 'In Search of the 'Structure that Reflects': Promoting Organisational Reflection Practices in a UK Health Authority' in: Vince, R. and Edwards, M., (Eds.) Organising Reflection, Blackwells, London, pp. 204219.

Clode, D. (2004) Integrated Working and Children's Services: Structures, Outcomes and Reform. Integrated Care Network, London.

Cooper, J.M. and Hutchinson, D.S (1997) Plato Complete Works (Hardcover). Hackett Publishing Company, USA.

Cooperrider, D.L. and Whitney, D. (2005), Appreciative Inquiry: A Positive Revolution in Change, Berrett-Koehler; 1 edition, New York. 
Craig, R. T. (1989). Communication as a practical discipline. In B. Dervin, L. Grossberg, B. J. O'Keefe, \& E. Wartella (Eds.), Rethinking communication; Volume 1: Paradigm issues (pp. 97-122). Newbury Park, CA: Sage.

Craig, R. T. (2007). Pragmatism in the field of communication theory. Communication Theory, $17(2), 125-145$.

Davies, P. (1999) 'Making sense of integrated care in New Zealand', Australian Health Review, 22(4), 25-44.

Dewey, J. (1933) How we think, a restatement of the relation of reflective thinking to the educative process. Boston: D.C. Heath.

Dewey, J. (1935) Liberalism and Social Action. New York: G.P. Putnam's Sons.

DfES (Department for Education and Skills) (2003) Every Child Matters, London: Department for Education and Skills.

DH (Department of Health) (2002) Learning From Past Experience: A Review of Serious Case Reviews. London: Department of Health.

DHSS (Department of Health \& Social Security) (1982) Child abuse: A study of inquiry reports 1973-1981. London: Department of Health \& Social Security.

Fischer, F. (2003), Reframing Public Policy: Discursive Politics and Deliberative, OUP Oxford, Oxford.

Fischer, F., (2009), Democracy and expertise: Reorienting public policy, New York: Oxford University Press.

Flyvbjerg, B. (2001), Making Social Science Matter: Why Social Inquiry Fails and How it Can Succeed Again, Translated by Sampson, S. Cambridge University Press, Cambridge.

Ford, J.D. and Backoff, R.W. (1988) 'Organizational change in and out of dualities and paradox', In Quinn, R. and Cameron, K. (Eds.), Paradox and Transformation: Towards a Theory of Change in Organization and Management. Cambridge, MA: Ballinger, pp. 81121.

Forester, J. (1983) 'Critical theory and organizational analysis', In G. Morgan (Eds.), Beyond Method: Strategies for Social Research. Newbury Park: Sage Publications, pp 234-346.

Forester, J. (1999), The Deliberative Practitioner: Encouraging Participatory Planning Processes, The MIT Press, Illustrated edition, Boston.

Gadamer, H.G. (1960/1989) Truth and Method (2 ${ }^{\text {nd }}$ Edition.). Boston: The MIT Press.

Gatto, T. (1991) Dumbing Us Down: The Hidden Curriculum of Compulsory Schooling. Canada: New Society Publishing.

GLA (Greater London Authority), (2007), Greater London Authority Act 2007, http://www.opsi.gov.uk/acts/acts2007/pdf/ukpga_20070024_en.pdf

Goethe, J. (1987) Collected Works V12: Scientific Studies, Suhrkamp, Germany. 
Gustavsen, B. (1992) Dialogue and Development: Theory of Communication, Action Research and the Restructuring of Working Life. Netherlands: Van Gorcum.

Gustavsen, B. (2003) Action Research and the Problem of the Single Case. Concepts and Transformation, 8(1), 93-99.

Habermas, J. (1979) Communication and the Evolution of Society (T. McCarthy, Trans). Polity Press, Oxford.

Habermas, J. (1985) The Theory of Communicative Action: Volumes 1 \& 2. Beacon Press, Boston.

Hegel, G.W.F. (1806/1975) Phenomenology of Mind, (Phenomenologie des Geistes), (A.V. Miller, Trans) Oxford University Press, Oxford.

Heisler, Ron (1989) 'Michael Maier and England', The Hermetic Journal.

HMSO (2004) Children Bill. London: HMSO.

Hunter, D.J. (1992) 'Doctors as managers: poachers turned gamekeepers?', Social Science and Medicine, 35(4), 557-566.

Jaques, (1976) Jaques: A General Theory of *Bureaucracy. New York: John Wiley \& Sons Inc.

Jaworski, J. (1996) Synchronicity: Inner Path of Leadership. San Francisco, CA: Berrett-Koehler Publishers Inc.

Kakabadse, A. and Kakabadse, N. (2002), 'Making 'modernising government initiatives' work: culture change through Collaborative Inquiry (CI)', Public Administration and Development, Vol. 22, No. 4, pp. 337 - 352.

Kakabadse, N., Kakabadse, A. and Kalu. K., (2007), 'Communicative Action through Collaborative Inquiry: Journey of a Facilitating Co-Inquirer, System Practice and Action Research, Vol. 20, No. 3, June, pp. 245 - 272

Kakabadse, N., Kakabadse, A. and Kalu, K. (2007), 'Communicative Action through Collaborative Inquiry: Journey of a Facilitating Co-Inquirer', Systemic Practice and Action Research, Vol. 20, No. 3, June, pp. 245-27.

Kakabadse, N.K. and Kakabadse, A. (2003) 'Developing Reflexive Practitioners Through Collaborative Inquiry: A Case Study of the UK Civil Service', International Review of Administrative Sciences, 69, 365-383.

Kant, I. (1929) Critique of Pure Reason, (N.K. Smith, Trans). Macmillan, London.

Karoly, L.A. and Panis, C. (2004) The 21st Century at Work: Forces Shaping the Future Workforce and Workplace in the United States: MG-164-DOL. RAND, California.

King, L., Lee, J.L. and Henneman, E. (1993) 'A collaborative practice model for critical care', American Journal of Critical Care, 2, 444-449.

Kohlberg, L. (1981) The Philosophy of Moral Development: Moral Stages and the Idea of Justice. Harpercollins, USA. 
Laming, L. (2003) The Victoria Climbie Inquiry (Command Paper No. 5730). The Stationery Office Books, London.

Linder, S. H., (2001), An inquiry into dialogue, its challenges and justifications $\square$, International Journal of Public Administration, 24; pp. 652-78.

London, S. (2005), 'The Power of Deliberative Dialogue' in Kingston, R.J. (Eds.), Public Thought and Foreign Policy, Dayton, Ohio: Kettering Foundation Press.

Luke, T.W. and White, S.K. (1985) 'Critical Theory, the Informational Revolution, and an Ecological Path to Modernity', In J. Forester (Ed.) Critical Theory and Public Life. Cambridge, MA: MIT Press, pp. 22-56.

Mansbridge, J., Amengual, M., Hartz-Karp, J. and Gastil, J., (2006), 'Norms of deliberation: an inductive study', Journal of Public Deliberation, 2(1), pp. 1-47.

Maranhao, T. (1986) Therapeutic Discourse and Socratic Dialogue: A Cultural Critique. The University of Wisconsin Press, USA.

Matthews, G.B (1981) Philosophy and the Young Child. Harvard University Press, London.

Mazen, M. (2002) Defensiveness is the Virus. Oxford: Blackwell.

McCallin, A. (2001) 'Interdisciplinary practice - a matter of teamwork: an integrated literature review', Journal of Clinical Nursing, 10(4), 419-428.

McEldowney, J. (2003), 'Public-management reforms and administrative law in local public services in the UK', International Review of Administrative Science, Vol. 69, No. 1, pp. 29-49.

Merchant, C. (1982), The Death of Nature, London: Wildwood House

Milburn, A. (2002) Report of Parliamentary Proceedings. London: HMSO.

Mill, J.S (1863/2002) Utilitarianism (2 ${ }^{\text {nd }}$ Edition), Hackett. Publishing Co, Inc, Massachusetts.

Ming-Jer Chen (2002), Inside Chinese Business: A Guide for Managers Worldwide, Harvard Business School Press, Boston.KPMG (2010), Tough Choices Ahead: The Future of the Public Sect, KPMG International.

Moustakas, C. (1981) 'Heuristic Research', In P. Reason and J. Rowan, (Eds.) Human Inquiry: A Sourcebook of New Paradigm Research. Chichester: John Wiley \& Sons Ltd.

Nelson, L. (1949) Socratic Method and Critical Philosophy. New Haven: Yale University Press.

Palfrey, J.G. (1865) History of New England During the Stuart Dynasty. Boston: Little, Brown and Company.

Peters, M. and Robinson, V. (1984) 'The Origins and Status of Action Research', The Journal of Applied Behavioral Science, 20(2), 113-124.

Plato, (1997), Defence of Socrates. Oxford: Oxford University Press.

Poulton, B.C. and West, M.A (1993) 'Effective multidisciplinary teamwork in primary health care', Journal of Advanced Nursing, 18, 918-925. 
Raelin, J. (2001), 'Public Reflection at the Basis for Learning', Management Learning, Vol. 32 (1), pp. 11-30.

Raelin, J. (2002), 'I don't have time to think! Versus the Art of Reflective Practice', Reflections, Vol. 4, No.1, pp. 66-74.

Reason, P. (1994) Participation in Human Inquiry. London: Sage Publications Ltd.

Reason, P., and Bradbury, H. (Eds.), (2006), Handbook of Action Research: Concise paperback edition, London: Sage Publications

Reich, R. (1998) 'Confusion about the Socratic Method: Socratic Paradoxes and Contemporary Invocations of Socrates', Philosophy of Education Yearbook 1998.

Revans, R. (1997), 'Action Learning: Its Origin and Nature', in: M. Pedler (Ed.) Action Learning in Practice, 3rd Ed. Aldershot: Gower, pp. 3-14.

Reynolds, M. (1999), 'Critical Reflection and Management Education: Rehabilitating less Hierarchical Approaches', Journal of Management Education, 23 (5), pp. 537-53.

Robinson, R. (1971) "Elenchus," In G. Vlastos, (Ed.), The Philosophy of Socrates: Collection of Critical Essays. USA: University of Notre Dame Press. pp. 78-93.

Ronald, A. C. (1992) Dialogic Education: Conversation About Ideas and Between Persons. Carbondale, So, Illinois University Press.

Rorty, R. (1988) 'Straussianism, Democracy, and Allan Bloom, 1: That Old-Time Philosophy', The New Republic, 198(14), 28-33.

Ryfe, D.M. (2002), 'The practice of deliberative democracy: a study of 16 deliberative organizations', Political Communication, 19, 359-377.

Ryfe, D.M. (2005), 'Does deliberative democracy work?' Annual Review of Political Science, 8 (1): 49-71.

Schleiermacher, F. (1998), Schleiermacher: Hermeneutics and Criticism: And Other Writings, edited by Andrew Bowie Cambridge University Press, Cambridge.

Seeskin, K. (1986) Dialogue and Discovery: Study in Socratic Method. State University of New York Press, New York.

Shotter, J. and Katz, A. (1996) 'Articulating a practive from within the practice itself: establishing formative dialogues by the use of a 'social poetics', Concepts and Transformation. 1(2/3), 227-238.

Siegel, D. and Rasmussen, K. (Eds.), (2008), Professionalism and Public Service: Essays in Honour of Kenneth Kernaghan, University of Toronto Press, Toronto.

Socrates, (1961) The Collected Dialogues: Apology, Euthyphro, Gorgias and Republic, edited by Cairns, Huntington and Hamilton, Edith. Princeton University Press, Princeton.

SSSS (Secretary of State for Social Services) (1974) Report of the Committee of Inquiry into the Care and Supervision provided in relation to Maria Colwell. London: HMSO.

Steiner, R. (1985) (Ed.) Goethe's World View. Mercury Press, New York. 
Stewart, J. and Zediker, K.Z. (2000), 'Dialogue as tensional, ethical practice', Southern Communication Journal, 65: 224-42.

Stewart, J., Zediker, K.Z. and Black,L. (2004), 'Relationships among philosophies of dialogue $\square$, in Anderson, Rob; Leslie A. Baxter; \& Kenneth N. Cissna, (Eds.), Dialogue. Theorizing Difference in Communication Studies, Thousand Oaks, California: Sage Publications, pp. 21-38.

Sutton, M. (2001) Policy research as ethnographic refusal: The case of women's literacy in Nepal. In M. Sutton and B. Levinson (Eds.), Policy as resource: Toward a comparative sociocultural analysis of education policy. Westport, CT: Ablex Press, pp. 77-99.

Taylor, C. (1985) Philosophical Paper: Volume 1, Human Agency and Language: Pt.1. Human Agency and Language. Cambridge University Press, Cambridge.

Torbert, W. R. (2001) The Practice of Action Inquiry. In P. Reason \& H. Bradbury (Eds.), The Handbook of Action Research: Participative inquiry and practice, London: Sage Publications, pp. 250-260.

Toulmin, S., and Gustavsen, B. (Eds.). (1996). Beyond Theory: Changing organizations through participation. Amsterdam: John Benjamins.

Van Manen, M. (1990) Researching Lived Experience: Human Science for an Action Sensitive Pedagogy. State University of New York Press, New York.

van Ruitenbeck, D. and Makin, P. (1999) 'Change in the public sector - for better or for worse' The British Psychological Society's Annual Occupational Psychology Conference, Blackpool, 5-7 January.

Vlastos, G. (1971), The Philosophy of Socrates: A Collection of Critical Essays, Notre Dame, In: University of Notre Dame Press.

Vlastos, G. (1991) Socrates: Ironist and Moral Philosopher. Cornell University Press, New York.

Vlastos, G. (1993) Socratic Studies. Cambridge University Press, Cambridge.

Von Goethe, J.W. and Naydler, J. (1996) Goethe on Science: An Anthology of Goethe's Scientific Writings. Floris Books, Edinburgh.

Whyte, W.F. (1991) Participatory Action Research. Sage Publications (USA), Thousand Oaks, CA.

Wilmot, S. (1995) 'Professional Values and Interprofessional Dialogue', Journal of Interprofessional Care, 9(3), 257-265.

Wittgenstein, L. (1980) Remarks on the Philosophy of Psychology (Volumes 1 \& 2). Oxford: Blackwell Publishers.

Yankelovich, D. (2001), Magic of Dialogue, Simon and Schuster, Reprint edition, New York. 
